\title{
State of International Development Uneven Progress, Shifting Policy Paradigms and Lessons for Pakistan
}

\author{
PARVEZ HASAN
}

\section{INTRODUCTION}

It is a great privilege to be invited to give the First Pakistan Development Economists' Society Lecture honoring Professor Gustav Ranis and his greatly acclaimed and wide ranging contributions to economic development theory and practice, human development, and institution building at Yale, at UNDP, Pakistan and elsewhere. Gus Ranis has been a towering figure in development economics, a distinguished Professor of Economics at Yale, Director of Yale centers for Economic Growth Center and International and Area studies, an Assistant Administrator of US AID, and, last but not least, effectively the first Director of the Pakistan Institute of Development Economics.

He has formally or informally guided PIDE's work for decades, has been a good friend of Pakistan and has never lost interest in its development.

Gus was a contemporary and a friend of Mahbub ul Haq in mid 1950s at Yale and their friendship further ripened when Mahbub asked him to join him and others including Amartya Sen in the first UNDP report on Human Development in 1990. My relationship with Gus Ranis also goes back nearly a century again because of my studies at Yale. He had, as a member of my $\mathrm{PhD}$ thesis approving committee, some reservations about my draft submitted in 1960 but was happy to see that his points had been fully taken into account in the published version in Yale Economic Essays a year later. A dozen years later I found myself, as the lead economist of World Bank on the Philippines, the principal discussant of his Gus Ranis' ILO mission report on the Philippines. I must say that he accepted my criticisms of some of his conclusions with good grace and humour. Our paths have crossed frequently since then most notably at the World Bank and PSDE meetings.

My lecture today deals with some of subjects closest to Prof. Ranis' heart: progress in international development, impact of globalisation and lessons for Pakistan, the land of many missed economic opportunities.

The subject of this conference is Economic Sustainability in a Globalised World. How does one define Economic Sustainability in what will hopefully remain a globalised world?

Parvez Hasan <phasan@aol.com> is a former Chief Economist of the World Bank. He is also author of Pakistan Economy at the Cross-Roads, Oxford University Press. 
More than half a century ago, W. W. Rostow ${ }^{1}$ in formulating his theory of take-off into growth argued that if the rate of net capital formation and savings as a percentage of net national product (NNP) increases from about 5 percent to around 10-12.5 percent of NNP, radical changes in production techniques and perpetuation of new scale of investment would assure sustained economic growth of around 2 percent per capita assuming population is growing at 1-1.5 percent per annum. Rostow, however, laid down two more conditions of takeoff, substantial growth in one or two in branches of manufacturing activity and 'the existence or quick emergence of a political, social and institutional framework which exploits the impulses of expansion in the modern sector and the potential external economy effects of the takeoff '.

About the same time, W. Arthur Lewis had defined the central problem in the theory of economic development was 'to understand the process by which a community which was previously saving and investing 4 or 5 percent of its national income or less, converts itself into an economy where voluntary saving is running at 12-15 percent of National Income or more'.

It may appear at first sight that the thresholds of savings and investments suggested by Rostow and Lewis have been long met. There are now hardly any developing countries with the ratio of gross capital formation to GDP of less than 15 percent. Nevertheless, only a small number of developing countries have been able to attain steady and significant growth in per capita income over long periods of say several decades. There have been quite a few promising looking take- offs that ended in crash landings.

A closer look suggests that the centrality of saving and investment remains an issue for a number of developing countries. These days there is too much focus on rates of gross capital formation. Rostow's concepts of net savings and investments are largely forgotten. Using the concept of net capital formation, i.e., after allowance for consumption of capital, the investment and savings ratios, while showing a wide variation appear less than robust for a significant number of major developing countries.

According to recent World Bank data, in most developing countries annual consumption of fixed capital is in the range of $8-12$ of gross national income (GNI). ${ }^{3}$ Table 1 presents the adjusted saving investment data. Net investment to GDP ratios are exceptionally high for only China and India 34.8 and 25 percent respectively, while they are below 12 percent for half the countries including Pakistan (using more recent data). On the savings side the picture is a bit better though several large countries Brazil, Mexico, Pakistan (again using recent data), and Turkey have net saving ratios of less than 10 percent and three African countries, Tanzania, Ethiopia, and Kenya have ratios of less than 5 percent. ${ }^{4}$

This suggests that for a number of countries saving and investment rates are much below what would be considered as minimum to ensure sustain growth especially as population growth at about 2.0 percent per annum in low income countries (excluding China) remains above the level assumed by him.

${ }^{1}$ W. W. Rostow, The Take off into Self sustained Economic Growth, The Economic Journal, Volume 66 March 1956, pp. 25-48.

${ }^{2}$ W. Arthur Lewis Economic Development with Unlimited Supplies of Labour, Manchester School May 1954.

${ }^{3}$ World Bank, 2008 World Development Indicators, Table 3.16.

${ }^{4}$ Very high rate of reported net savings for some countries notably Philippines, Nigeria, Morocco, and Bangladesh may partly reflect the considerable differences between their GNI and GDP because of worker remittances. In any case the comparison. 
Table 1

\begin{tabular}{lcccc}
\hline & $\begin{array}{c}\text { Gross Capital } \\
\text { Formation } \\
\text { as a } \%\end{array}$ & $\begin{array}{c}\text { Capital } \\
\text { Consumption } \\
\text { Allowance } \\
\text { as\% of GNI }\end{array}$ & $\begin{array}{c}\text { Net Capital } \\
\text { Formation } \\
\text { as \% of GDP }\end{array}$ & $\begin{array}{c}\text { Net Saving } \\
\text { as of } \\
\text { GNI }\end{array}$ \\
\hline Bangladesh & 25.0 & 8.1 & 16.9 & 23.2 \\
Ethiopia & 12.0 & 6.9 & 5.1 & 2.5 \\
India & 34.0 & 9.0 & 25.0 & 24.7 \\
China & 45.0 & 10.2 & 34.8 & 43.6 \\
Sri Lanka & 29.0 & 9.7 & 19.3 & 15.1 \\
Vietnam & 21.0 & 9.0 & 12.0 & 28.7 \\
Pakistan & 22.0 & 8.4 & 13.6 & 14.7 \\
Indonesia & 25.0 & 10.4 & 14.6 & 17.2 \\
Egypt & 19.0 & 10.4 & 10.2 & 12.3 \\
Thailand & 28.0 & 9.8 & 17.8 & 20.0 \\
Philippines & 14.0 & 8.4 & 5.6 & 22.1 \\
Morocco & 32.0 & 10.5 & 21.5 & 24.5 \\
Nigeria & 22.0 & 10.2 & 11.8 & 28.5 \\
Colombia & 24.0 & 11.4 & 10.6 & 9.5 \\
Turkey & 24.0 & 11.7 & 12.3 & 4.9 \\
Korea & 30.0 & 13.3 & 16.7 & 17.1 \\
Malaysia & 21.0 & 12.1 & 8.9 & 20.6 \\
Mexico & 22.0 & 12.4 & 9.6 & 9.8 \\
Brazil & 17.0 & 12.0 & 5.0 & 5.8 \\
Chile & 20.0 & 14.2 & 5.8 & 13.4 \\
Argentina & 24.0 & 12.0 & 12.0 & 15.0 \\
Kenya & 19.0 & 9.6 & 9.4 & 0.5 \\
Tanzania & 19.0 & 7.8 & 11.2 & 3.6 \\
Algeria & 30.0 & 11.8 & 18.2 & NA \\
USA & 19.0 & 12.2 & 6.8 & 1.9 \\
\hline So & G. & & &
\end{tabular}

Source: World Bank: 2008 Development Indicators.

To add to the challenge, notions of what are considered as necessary rates of economic growth have changed over time. The population explosion and the needs of adequate job creation have pushed the desired per capita annual growth levels to 4-5 percent or higher. Indeed, in China, even though the labour force is now growing slowly, it is felt that per capita GDP growth of at least 7-8 percent per annum is needed for many years to take care of the large overhang of underemployed labour in agriculture.

So economic sustainability should obviously relate to some minimum desired rate of economic growth that would ensure adequate job creation and a steady reduction in poverty incidence in a particular country context. However, it is doubtful that sustained growth rates of per capita income of less than 3-4 percent per annum would be adequate for most developing countries in the initial stages of development. How does the record look in light of these admittedly somewhat arbitrary criteria? 


\section{ECONOMIC GROWTH RECORD}

The last half century has been a period of rapid growth in world economy and international trade. Export led growth, more market oriented policies, higher savings and investments, and much larger international private investment flows have all contributed to accelerated growth and, to an extent, shared prosperity. Economic advancement in East Asian countries and more recently in China and India has been an outstanding success story though the deepening international recession and economic setback may take some luster out of their performance.

Despite considerable progress, development challenges remain huge. The latest Purchasing Power Parity (PPP) GDP per capita figures for 2007, based for the first time on comprehensive surveys in 2005 , do not provide a great deal of comfort about international development. (Table 2) India, China, Indonesia, Brazil, Pakistan, Bangladesh, Nigeria, Mexico, Philippines, Vietnam, Ethiopia, Egypt, twelve of the largest developing countries by population have, as a group, income level only about 9 percent of the per capita GDP of the United States in PPP terms, using US as a rough proxy for the developed world.

Brazil and Mexico, the highest income of these developing countries had per capita income respectively of 20.9 and 27.9 percent of the US level. (As a reference, South Korea was at 54.0 percent). On the poorest end, Bangladesh and Ethiopia had relative income levels respectively of 3.0 and 1.4 percent compared to the US. So the disparities among the developing countries are also huge.

Table 2

PPP based Per Capita GDP Most Populous Developing Countries Compared to US

\begin{tabular}{lcccc}
\hline & & & & Economic Size \\
& Population, & GDP Per & GDP Per & $\begin{array}{c}\text { GNI PPP } \\
\text { Capita }\end{array}$ \\
Country & 2007 & Capita & PPP \$, 2007 & International \$ \\
In Millions & PPP \$, 2007 & As \% of US & In Billion \\
\hline China & 1320 & 5046 & 11.7 & 7083.5 \\
India & 1123 & 2599 & 6.0 & 3078.7 \\
Indonesia & 226 & 3519 & 8.1 & 807.9 \\
Brazil & 192 & 9034 & 20.9 & 1759.7 \\
Pakistan & 162 & 2383 & 5.5 & 417.5 \\
Bangladesh & 159 & 1242 & 2.9 & 212.7 \\
Nigeria & 148 & 1866 & 4.3 & 262.5 \\
Mexico & 105 & 12070 & 27.9 & 1324.6 \\
Philippines & 88 & 3218 & 7.4 & 327.8 \\
Vietnam & 85 & 2454 & 5.7 & 216.9 \\
Ethiopia & 79 & 735 & 1.7 & 61.7 \\
Egypt & 75 & 5052 & 11.7 & 407.6 \\
USA & 302 & 43227 & 100 & 13829.0 \\
\hline
\end{tabular}

Source: World Bank Economic Data Division. 
China despite its immense progress during the last few decades had a per capita income of less than 12 percent of the US level in 2007 and among others only Egypt had an equivalent per capita. India, the second most populous country in world, had average income level only 6 percent that of US. Indonesia and Philippines were in between China and India while Pakistan, and Vietnam, were closer to the latter with Nigeria considerably behind.

Clearly the gap between the rich and poor countries remains very large but is it narrowing? Or more importantly, how many developing countries have met the test of at least 3-4 percent per capita growth over the last several decades. Admittedly, the levels of income are only one facet of progress. Other dimensions, human development, poverty incidence, income inequality, law and order, access to justice, environmental change are also critically important and intertwined with economic growth and are being given much more attention by all social scientists, policy makers and the international community than just a few decades ago. Still, adequate growth in average incomes in developing countries across the globe remains fundamentally important for world peace and prosperity.

There are of course some problems with most measures of change in per capita incomes over time.

The most frequently used tool for comparison is the rate of growth of per capita GDP based on national data. This has broad relevance but also some limitations. For instance, the GDP measure does not capture major variations in the fortunes of countries caused by sharp secular changes in the terms of trade reflecting major shifts in relative prices of key internationally traded goods and services and does not take into account the impact of net service income or payments abroad and private transfers such as worker remittances. Also the growth rates of domestic output can be distorted if large parts of agriculture and/or industry are heavily protected and not internationally competitive.

The World Bank GNI measure takes into account net income and transfers from abroad and terms of trade changes but does not provide a constant price series over time. Purchasing power parity estimates of GDP complemented by GNI measure can provide a better indication of relative shifts in incomes among countries. But consistent PPP based series based on regular relatively short interval are not available. Hopefully, the ICP project will intensify it updating work and conduct a fresh survey at least every five years.

I have attempted in Table 3 to provide the average annual per capita GDP growth rates over 1980-2007 for a couple of dozen countries (including the dozen most populous) by using two different sets of data and method. First sets of growth rates are those derived conventionally from the national accounts data. The second estimates of growth rates are based World Bank Atlas method data on GNP/GNI in current US \$ for 1980 and 2007 adjusted for inflation in US dollars of 126.5 percent over 1980-2007 or 3 percent per annum. The gains in per capita incomes for most countries by this method appear much smaller than those indicated by national account figures.

On the GDP growth data, there is no surprise that only China, Korea, Thailand and Vietnam had very satisfactory per capita growth rates exceeding 4 percent per annum. India, Sri Lanka, Chile, Indonesia and Malaysia had also good annual growth rates of between 3-4 percent. But in the next rung Turkey, Egypt, Pakistan, and Bangladesh with growth rates between 2-3 percent did not meet what I would consider a minimum sustainable threshold of 3 percent per annum. 
China is clearly an outlier with an annual growth rate of per capita GDP of 8.5 percent over 1980-2007. But this growth rate appears to be exaggerated because the interpolation puts the Chinese GDP in 2005 constant prices at \$525 in 1980 not only well below Pakistan (\$1191), India (\$889), but considerably below Bangladesh (\$614) and Ethiopia (608). This does not seem quite plausible. The first World Bank economic mission to China, that I headed in 1980, found that Chinese GDP at that time was only moderately lower than the Indian GNP according to World Bank Atlas methodology (see Table 3).

Many large countries including Nigeria, Ethiopia, and Philippines, Mexico and Brazil and a few smaller ones Kenya, Tanzania, and Argentina show growth rate of less than 1 percent per annum.

Using the World Bank Atlas data over time, the implicit real growth rates appear much more modest though the order ranking by countries does not change much. China and Korea retain their outlier status followed by Vietnam, Sri Lanka and Thailand. Among other countries only Turkey, Chile, Malaysia, India matched or bettered the US the per capita growth rate of 1.7 percent per annum over 19802007. Thus according to this method 15 countries including Pakistan out of 24 lost relative ground to the US.

Table 3

\begin{tabular}{|c|c|c|c|c|}
\hline Countries & $\begin{array}{c}\text { Average Annual } \\
\text { Growth Rate of Per } \\
\text { Capita GDP } \\
\text { 1980-2007 }\end{array}$ & $\begin{array}{l}\text { Per Capita GNP/ } \\
\text { GNI, According to } \\
\text { World Bank Atlas } \\
\text { Method in Current } \\
\text { US \$ } \\
1980\end{array}$ & $\begin{array}{l}\text { Per Capita GNP/ } \\
\text { GNI, According to } \\
\text { World Bank Atlas } \\
\text { Method in Current } \\
\text { US \$ } \\
2007\end{array}$ & $\begin{array}{c}\text { Real Annual } \\
\text { Average Growth } \\
\text { Rates of Per Capita } \\
\text { GNP/ GNI, as } \\
\text { Adjusted by US } \\
\text { GDP Average } \\
\text { Deflator Growth of } \\
3 \text { percent Per } \\
\text { Annum }\end{array}$ \\
\hline Bangladesh & 2.6 & 200 & 470 & 0.1 \\
\hline Ethiopia & 0.8 & $320(1981)$ & 220 & -3.0 \\
\hline India & 4.0 & 270 & 950 & 1.7 \\
\hline China & 8.5 & 220 & 2360 & 6.1 \\
\hline Sri Lanka & 3.6 & 280 & 1540 & 3.4 \\
\hline Vietnam & $5.0(1984-2007)$ & 220 (1989) & 790 & 4.2 \\
\hline Pakistan & 2.6 & 330 & 870 & 0.6 \\
\hline Indonesia & 3.5 & 500 & 1650 & 1.4 \\
\hline Egypt & 2.7 & 500 & 1580 & 1.2 \\
\hline Thailand & 4.6 & 720 & 3400 & 3.0 \\
\hline Philippines & 0.8 & 690 & 1620 & 0.1 \\
\hline Morocco & 1.8 & 970 & 2250 & 0.1 \\
\hline Nigeria & 0.3 & 780 & 930 & -2.4 \\
\hline Colombia & 1.6 & 1190 & 3250 & 0.6 \\
\hline Turkey & 2.6 & 1920 & 8020 & 2.3 \\
\hline Korea & 5.9 & 1810 & 19690 & 6.4 \\
\hline Malaysia & 3.5 & 1830 & 6540 & 1.7 \\
\hline Mexico & 0.9 & 2520 & 8340 & 1.3 \\
\hline Brazil & 0.7 & 2190 & 5910 & 0.5 \\
\hline Chile & 3.6 & 2240 & 8350 & 1.9 \\
\hline Argentina & 0.8 & 2940 & 6050 & -0.4 \\
\hline Kenya & 0.5 & 460 & 680 & -1.6 \\
\hline Tanzania & 1.2 & 190 (1990) & 400 & 1.4 \\
\hline Algeria & 0.8 & 2060 & 3620 & -1.0 \\
\hline USA & 2.0 & 12980 & 46040 & 1.7 \\
\hline
\end{tabular}

Source: World Bank Data Division. 
The list of economic laggards and failures is both long and depressing whatever the criterion used. In Africa, Ethiopia, Nigeria, Kenya, and apparently Algeria have been development disasters. In East Asia the Philippines has had a dismal record and has steadily lost ground to all its neighbors. In South Asia, sustained significant long term growth in Pakistan and Bangladesh has yet to find traction. In Latin America, Argentina and surprisingly Brazil and Mexico have also not shown strong long term growth.

This impressionistic survey also strongly suggests that economic fortunes of countries can change dramatically up and down in a single generation and, in my experience, that responsibility for change rests largely on the countries themselves. What explains the success stories? Or the equally important question what accounts for poor economic performance?

\section{SEARCHING FOR SUCCESS}

Economists, policy-makers and international finance institutions especially the World Bank have continued to struggle with defining the ingredients of success or sources of failure for decades. On the whole, the development record is not too reassuring and policy prescriptions have not generally worked well in countries with the most difficult challenges. Obviously, there are no simple answers, no single formula for success and many roads to failure.

A recent volume by Shahid Yusuf, ${ }^{5}$ that critically analyses the evolution of thinking on development economics in the World Bank as encapsulated in the thirty World Development Reports (WDRs) since 1978, poses the questions "When the 'technology of development' is so widely shared — not the least through the WDRs—why are there so many laggards? Why aren't the ranks of 'tiger economies' growing by the year?"

In the rest of paper, I examine some of these questions in light of both empirical evidence and my own development experience stretching over several decades and some twenty countries including Pakistan and many so-called East Asian tigers. I then focus on drawing some lessons that seem relevant for Pakistan and highlighting desired policy goals and imperatives that have so often eluded us in the past.

\section{EXPORT ORIENTED GROWTH}

The starting point must be East Asia, where manufactured goods export-led growth by the pioneers Hong Kong, Taiwan, Korea and Singapore in the 1960s established new standards of rapid growth. These examples were quickly emulated by Thailand, Malaysia, Indonesia and the Philippines in the 1970s. China started its spectacular push in exports in early 1980s.

In the same way as South Korea's development strategy drew its inspiration from examples of Japan, Taiwan and Singapore, China, under Deng Xiaoping, in its historic opening to the outside world starting as late as 1979, drew on the example of Hong Kong. Just a couple of decades ago, few could have imagined that a continental economy like China could make exports expansion its growth engine by turning large parts of its Eastern Coast into essentially free trade zones. In a generation, exports of goods and services from China

${ }^{5}$ Shahid Yusuf, Development Economics Through the Decades, A Critical Look at 30 years of the World Bank, The World Bank, 2009, p. 90. 
had risen to well a trillion dollars by 2007 or well over 40 percent of GDP. China is now by far the most export oriented large country in the world. Exports to GDP ratio of 23 percent and 11 percent for India and USA respectively compare unfavourably with China.

More recent success stories countries like Turkey and, Vietnam have also relied on exploiting the possibilities offered by almost explosive growth in international trade. Putting it another way, there are few cases of rapid economic advance in modern history that have not relied on exports as an engine of growth. But many countries notably Philippines and Mexico have not been able to translate high rates of growth of exports into sustainable high overall growth rates.

There are also big differences between China and the earlier export successes of countries like Korea, and Taiwan. Large foreign investments did not play that much of a role in rapid development of exports from East Asia as they have in China. Then there is the case of Pakistan where earlier successes in exports in 1960s and1980s were not sustained: its ratio of exports of goods and services to GDP actually declined to 17 percent in 2006.

\section{ROLE OF GLOBALISATION}

Many East Asian countries especially China deserves credit for taking full advantages of the forces unleashed by rapid globalisation. But it also should be noted that the spectacular growth rates of these countries would not have been possible without major liberalisation of world economic order.

The most important manifestation of phenomenon that is now called globalisation has been the expansion of world trade at a much faster pace than world output since the 1960s. The rapid expansion of world trade has been accompanied by wider dissemination of technologies, a greater role of intermediate products (or components) in structure of trade and greater role for multinational corporations in greater international specialisation. The sharply accelerated flows of private finance and greater reliance on foreign workers have further deepened globalisation trends at least until recently.

International trade flows have been stimulated by the steady liberalisation of trade policies and reduction of tariffs as well as by technological changes reducing transport costs and improving information flows. The leading edge of this expansion has been the growth in world manufactured goods exports which have increased steadily from less than $\$ 200$ billion in 1970 to $\$ 8.2$ trillion in 2006, showing an average real growth of 11 percent. While the nature of international trade in manufactures has changed quite significantly from finished goods to intermediate products or components, there was no trend of slowing down in the pace of this growth till 2007.

Given the increasing liberal trade framework, the shifting comparative advantage especially in labour-intensive manufactured goods has also meant that the share of developed countries (USA, Japan and EU15) in World manufactured exports has been declining. It came down from 75.8 percent in 1980 to 63.8 in 2000 and it is estimated to have dropped further to around 55 percent in 2006.

Table 4 shows that for the sixteen major developing countries/entities, manufactured exports rose nearly 30 times in the last quarter century, from $\$ 94$ billion in 1980 to $\$ 2.7$ trillion. For the world as a whole they grew by less than eight fold from $\$$ 1.1 trillion to $\$ 8.3$ trillion over the period. The average annual growth rate of developing countries' manufactured exports has been around 14 percent. 
Table 4

Major Developing Countries' Exports and Trend in Their Market Share of World Manufactured Exports

\begin{tabular}{|c|c|c|c|c|c|c|}
\hline Country & $\begin{array}{c}2006 \\
\text { Total } \\
\text { Exports in US } \\
\text { \$ Billion } \\
\end{array}$ & $\begin{array}{c}1980 \\
\text { Manufactured } \\
\text { Exports } \\
\text { In US\$ } \\
\text { Billion } \\
\end{array}$ & $\begin{array}{c}2006 \\
\text { Manufactured } \\
\text { Exports } \\
\text { in US\$ } \\
\text { Billion } \\
\end{array}$ & $\begin{array}{c}\text { Manufactured } \\
\text { Exports } \\
\text { Market } \\
\text { Share } \\
1980 \\
\end{array}$ & $\begin{array}{c}\text { Manufactured } \\
\text { Exports } \\
\text { Market } \\
\text { Share } \\
1995 \\
\end{array}$ & $\begin{array}{c}\text { Manufactured } \\
\text { Exports } \\
\text { Market } \\
\text { Share } \\
2006 \\
\end{array}$ \\
\hline$\overline{\text { China }}$ & 969.0 & 8.7 & 895.4 & 0.80 & 3.36 & 10.80 \\
\hline Hong Kong & 322.7 & 18.0 & 304.7 & 1.60 & 4.32 & 3.69 \\
\hline Korea & 325.7 & 15.7 & 290.1 & 1.43 & 3.08 & 3.50 \\
\hline Singapore & 271.8 & 8.3 & 214.1 & 0.76 & 2.66 & 2.59 \\
\hline Taiwan & 223.6 & 17.4 & 191.6 & 1.59 & 2.78 & 2.32 \\
\hline Mexico & 250.3 & 4.4 & 189.2 & 0.40 & 1.61 & 2.29 \\
\hline Malaysia & 160.6 & 2.4 & 117.9 & 0.22 & 1.48 & 1.42 \\
\hline Thailand & 130.6 & 1.6 & 98.4 & 0.15 & 1.11 & 1.19 \\
\hline India & 120.2 & 5.0 & 83.8 & 0.46 & 0.62 & 1.01 \\
\hline Brazil & 134.5 & 7.5 & 68.4 & 0.69 & 0.66 & 0.83 \\
\hline Turkey & 85.1 & 0.8 & 69.4 & 0.07 & 0.43 & 0.84 \\
\hline Indonesia & 104.0 & 0.5 & 44.4 & 0.05 & 0.62 & 0.54 \\
\hline Philippines & 47.0 & 2.1 & 40.6 & 0.19 & 0.37 & 0.49 \\
\hline Vietnam & 39.6 & - & 17.8 & - & NA & 0.24 \\
\hline Pakistan & 16.9 & 1.3 & 13.8 & 0.12 & 0.18 & 0.18 \\
\hline Bangladesh & 12.1 & 0.5 & 9.3 & 0.05 & 0.07 & 0.10 \\
\hline \multicolumn{7}{|l|}{ Total for above } \\
\hline Countries & $3,216.0$ & 94.1 & 2646.9 & 7.82 & 23.35 & 32.03 \\
\hline World Exports & $12,062.0$ & $1,092.4$ & 8256.8 & 100.0 & 100.0 & 100.0 \\
\hline
\end{tabular}

Source: WTO Statistical Tables.

Note: Figures for Singapore, Bangladesh and Vietnam relate to 2005.

The most important development was a hundredfold growth in Chinese manufactured exports and a spectacular rise in its share in world manufactured goods market from a paltry 0.8 percent in 1980 to 10.8 percent in 2006 .

But many other Asian countries did well also. The high performers of the 1960s and 1970s in East Asia (Korea, Singapore, Hong Kong Taiwan),) further expanded their dominant export positions. Relative new comers to the field, Malaysia, Thailand, India, Vietnam and Philippines also did well. Outside Asia only Mexico, Turkey, and Chile made notable gains.

\section{ROLE OF THE STATE}

Next to the favourable and improving international economic environment, the role of state in providing a vision and a strategy for development has often been critical. Apart from China, Korea, Singapore, Taiwan, Malaysia, and more recently India have all strongly benefited from positive directions provided by a reformed or reforming state. In Turkey export development and trade reform did not become a priority till the deep foreign exchange crisis of late 1970s led to many Turks being deprived of heat in a bitter winter and suffered acute shortages of their beloved coffee.

In Korea, with which I was involved heavily over 1973-84, manufactured exports were almost negligible in early 1960s and saving and investment and balance of payments gaps were huge. Park Chung He who assumed leadership in 1961, put his trust 
in export development and export led growth became almost a religion in Korea during the 1960s and the 1970s. Exports trends were monitored monthly by a high level meeting chaired by the President and attended both by high economic officials and leading exporters with a view to coordinate policy and to do trouble shooting. As a result of this almost single minded focus, manufactured exports from Korea that were a modest $\$ 100$ million even by 1965 grew quickly to $\$ 600$ million by 1970 and were to exceed $\$ 10$ billion mark by $1980 .{ }^{6}$ Merchandise exports from Korea in 2006 were $\$ 325$ billion.

The Korean export drive would not have been quite so successful if in early 1970 s the Korean Planning Board had not, again under the direction of President Park, drawn up an ambitious plan to diversify and deepen the export and industrial structures. Till that time the Korean exports were heavily concentrated in labour-intensive manufactured goods such as textiles: textiles, clothing, footwear and wigs accounted for nearly 70 percent of manufactured goods exports in 1970.

Recognising that relatively low skill intensive manufactured exports will be losing their comparative advantage as real wages had started to rise sharply, the political leadership launched a long term plan in 1973 to develop more skill and capital intensive heavy industries including steel and shipbuilding as well as electronics, the new growth pole in international trade. A part of this plan was to expand research and development activity.

Apparently, the impulse for shipbuilding came directly from President Park personally who wanted to emulate and ultimately challenge Japan's dominant place in world shipbuilding at the time. He felt that Korea's location, climate and educated and disciplined labour force could all eventually help match Japanese's competitive edge. He had to actively encourage private entrepreneurs like Hyundai Group to take the risks in a field totally new to them. But he had the foresight not to create a monopoly by involving at three Chaebols in the field. Finally in launching the ship building industry as in many other areas of manufacturing including garments, textiles and electronics, Koreans did not insist on strong backward linkages right away and were content initially to rely heavily on imported managerial skills, technology and equipment.

The foray into shipbuilding has probably exceeded beyond Korea's wildest expectations. In April 2006, Korean shipyards occupied the first seven of the ten top places in terms of order backlogs, the next two were Chinese and the tenth was the Japan industry leader Mitsubishi Heavy industries.

It needs to be noted, however, that in some other areas of heavy and chemical industries, the state interventions did not succeed at least initially because of excessive ambitious plans.

In sharp contrast to East Asian countries, Pakistan's export performance has been very disappointing. Pakistan's share in world manufactured exports at 0.18 percent is lower than it was in 1970. Pakistan has lost relative ground over time to all the major developing countries listed in the above Table 4 with the exception of Brazil.

${ }^{6}$ Contrary to impressions, Korea's rapid industrial growth was not generally associated with excessive protection of domestic industry or unduly large incentives for exports. While Korea relied heavily on a variety of export incentives till the early 1970s (nearly 32 percent in of export value in 1970), their main purpose was to compensate for the lags in the adjustment of the exchange rate and the high cost of imported intermediate products. The real effective rate of subsidy on exports of manufactured goods was in the range of 9-12 percent in late 1960s-probably a peak. See Parvez Hasan, Korea, Problems and Issues in a Rapidly Growing Economy, John Hopkins University Press, 1976. 


\section{WHY PAKISTAN FELL BEHIND?}

Why has Pakistan fallen so far behind in the export field? There are several reasons that are rooted in past policies and attitudes towards exports. First, exports growth has never been a central pillar of development strategy a la Korea, Malaysia, and China. Second, exports were not as profitable as sales in the domestic markets which were heavily protected for a long period. The anti-export bias in policy was reinforced by an industrial strategy that favoured manufacturing based on processing of domestic raw materials. Export development based on imported inputs was strongly discriminated against by generally high duties on imports. Finally, the spurts of export growth that materialised in 1960s and 1980s were to a substantially extent artificially supported by indirect subsidies to the textile sector that kept the domestic price of cotton well below the international price and thus encouraged relatively low value added textile exports notably cotton yarn.

Pakistan has the least diversified pattern of manufactured exports with the exception of Bangladesh. More than 80 percent of Pakistan's manufactured exports consist of textiles and clothing compared with less than 12 percent for developing countries as a group and 6.5 percent for world as a whole. While Pakistan is a major exporter of textiles and clothing, accounting for 2.1 percent of world exports, its exports of manufactured exports other than textiles and clothing are very small. At $\$ 2.7$ billion in 2006 they were only 0.033 percent of world manufactured goods exports totaling nearly $\$ 8$ trillion. India's manufactured exports (excluding textiles and clothing) are nearly twenty five times that of Pakistan while countries like Philippines, Indonesia, Turkeyby no means stellar performers in the export field-have other manufactured goods export levels around 15 times that of Pakistan's. Even a newcomer like Vietnam enjoys a 5-fold advantage over Pakistan in this regard. Quite clearly public policies must share a significant part of the blame for the present structure of Pakistan's exports with its continued heavy dependence on textiles.

\section{GOOD GOVERNANCE AND EFFICIENCY IN USE OF RESOURCES}

Attention to manufactured exports and the state role in promoting exports cannot alone explain the East Asian Miracle. Many other factors like political stability, strong institutions, high levels of human capital, ability to handle negative economic shocks and economic crises effectively all contributed to the remarkable economic outcomes. They were ultimately reflected both in the level of mobilisation of resources for development and the efficiency of resources use as measured by the growth in total factor productivity. ${ }^{7}$ But there were important differences among countries in these two respects.

The high rates of economic growth in Korea, as in Japan, Taiwan, and Hong Kong and more recently in China and unlike Malaysia, Indonesia, and Singapore were made possible by rapid growth in total factor productivity as well as sharp increases in inputs of capital and labour. According to a World Bank study, total factor productivity growth in Korea, Taiwan, Hong Kong over 1960-1989 was around 3.5 percent per annum. ${ }^{8}$ Over the

${ }^{7}$ Export development also improves TFP by inducing technical change and shifting the economic structure towards more higher economic value added activities.

${ }^{8}$ World Bank 1993. 
same period, the factor productivity growth for most developing economies (excluding high performing East Asian countries) was negative or less than 1 percent per annum.

The recent estimates for China indicate that factor productivity rose steadily in both agriculture and non-agriculture sectors from 1.5 and 1 percent per annum respectively to over 3 percent by $2004 .{ }^{9}$ But as noted earlier, if the Chinese growth rates are somewhat exaggerated, the factor productivity estimates would also need to be revised downwards.

In terms of productivity, the contrast between the Philippines and Korea is instructive because it confirms that export growth alone cannot turn the economy around. The growth rate of exports from the Philippines has been consistently high and share of exports of goods and services in the economy has increased further from 36 percent in 1990 to 46 percent in 2006 propelled by strong growth of manufactured goods (Table 4) as well as worker remittances. Still Philippines remains an important economic laggard in Asia.

Total factor productivity data for the Philippines is not readily available. However, its incremental capital: output ratios (ICORS) remained persistent high around 4.5: 1 during 1960-2000 and were at least 50 percent higher than that in Korea in the 1970s, even though industrial deepening and capital intensive investments had already taken off in Korea by then. At one time, I estimated that if the Philippines had the same capital; output ratio in the 1960s and the 1970 as Korea had, its growth rate would have been at least 50 percent higher than it actually was.

The broad efficiency of resource use was particularly important in Korea in the early stages of its development because initially the weight of exports in the economy was small. The ratio of manufactured exports to gross manufacturing output was only 5 percent in 1960. Even after very rapid growth in manufactured exports during this was only 15 percent in $1970 .{ }^{10}$ It reached the peak of 40-45 percent share in the 1990 s and now stands at around 40 percent.

The contribution that very proficient and modern construction industry, which largely developed through the large scale infrastructure spending after the end of the Korean War in early 1950s, made to keeping capital costs low is less well known. In general also good organisation and greater internal management and labour discipline meant that projects could be completed more speedily than in most other countries. Finally, low capital: output ratios in Korea provide indirect evidence that corruption was low and leakages and underhand payments that ultimately increase project costs were not very significant. In the Philippines, in sharp contrast, high levels of corruption led to artificially inflated costs of projects that were ultimately reflected in the high ICORs.

\section{SHIFTING PARADIGMS: MARKETS, GOVERNANCE AND INSTITUTIONS}

While most East Asian countries were flourishing, for many developing countries, "the 1970s were a decade of creeping disillusionment—not development........and the 1980s turned out to be harsher" $" 11$ in part due to the two oil shocks that greatly

${ }^{9}$ Loren Brandt and others, "Growth and Structural Transformation in China" in China's Great Transformation Editors Loren Brandt and Thomas G. Rawski, Cambridge University Press 2008.

${ }^{10}$ Parvez Hasan and D.C. Rao, Korea Policy Issues for the Long Run, World Bank 1979.

${ }^{11}$ Shahid Yusuf (2008), pp. 23-24. 
exacerbated the foreign exchange problems of oil importing countries. The faith in state solutions waned and belief in market forces and competitive pressures gathered momentum. Under Ronald Reagan and Margaret Thatcher, two of the most influential politicians of the $1980 \mathrm{~s}$, a diminution of the regulatory state and with the partial dismantling of public sector through privatisation became the conventional wisdom. But as Ravi Kanbur notes the mainstream economics went "from a situation where state could do no wrong to one where the state could no right.....The pendulum swung too far the other way. That it began to swing the other way was due to experience. That it swung too far the other way was due to ideology". ${ }^{12}$

Economic thinking has continued to evolve. As getting prices right and increasing openness of the economies did not appear to solve development problems, the emphasis has shifted to the role of institutions in providing effective regulation through ensuring transparency and accountability, removing information gaps, removing barriers to entry and enforcement of property rights, contracts and of the rules that affect market functioning.

So under the rubric of what is loosely termed as good governance the state was back even before the current international crisis. It must provide strategic directions to the economy including exploiting of opportunities offered by globalisation as well as safeguarding against its excesses. It must ensure effective delivery of basic public services such as law and order, justice, education and health, infrastructure. And of course it must ensure proper functioning of the market economy.

But in order to achieve good governance, a country has to have reasonable political stability, a political leadership and elites who respect the rule of law, a bureaucracy and public bodies that are honest and efficient, political will to mobilise enough resources for running an effective government, and a right balance between national security and development needs. Pakistan has not performed well on these governance criteria and therefore it has not been able to match the record of high performing Asian economies despite its considerable potential and large inflow of resources from abroad.

Broadly speaking also it is poor governance that is mainly responsible for the plight of poor performing countries especially in Africa. Again in my experience, successful countries in East had reasonably strong bureaucracies with good internal discipline and coordination. Korea was outstanding but Malaysia also had a well paid and high caliber civil service. Pakistan started with a very strong administrative base but one that has declined both in standards of efficiency and integrity. But as the Philippines' case shows cultural factors do also influence public sector performance. Unfortunately good governance cannot be ordained and thus the economists are discovery the limits of technology of development.

But one should hasten to add that good governance alone is not the panacea and even with uneven governance, there may be ways to improve economic management and performance. Till 1980s China and India had reasonably good governance but not a very successful economic growth record. Pakistan has enjoyed periods of high growth with good economic management though governance remained a serious problem.

${ }^{12}$ Ravi Kanbur, The Development of Development Thinking, Cornell University, Ithaca New York 2005p.13 as quoted in Shahid Yusuf (2008). 
So even with uneven governance, there are ways to improve economic management and Pakistan can learn important lessons about development from the success stories in East Asia. But because developments in the international economic system have been a key part of economic success stories, the first question is whether globalisation will unravel under the pressure of prolonged global recession.

\section{WILL GLOBALISATION SURVIVE?}

International trade is expected to decline in absolute terms for the first time in half a century and private capital flows have already dropped precipitously. Protectionist pressures seem to be growing in many countries and protectionism has the danger of spreading to financial services. The next few years are likely to bring about major changes in which the globalised financial system is managed and regulated. The role of the IMF is very definitely likely to expand in managing major global imbalancesironically just a couple of years after a major downsizing of its staff due to budgetary concerns. These changes will put limits on leveraging by major financial institutions, a rethinking in developing countries about totally free capital markets, and more attention to longer-term structural issues in international finance especially the huge and sustained deficits in the US current account balance of payments that have proven to be the Achilles' heel of the globalised economic system.

It is my belief, however, that while major changes in the international financial system, introduction of appropriate regulation and safeguards, and much greater international cooperation on financial issues are necessary and would take place, the world trading system will emerge relatively unscathed from the present crises. Exports as an engine of world growth will survive because of the considerable gains that continuing international division of labour based on ever evolving comparative advantage promises.

The countries like China and Korea that export for 40-45 percent of their gross manufacturing output would undoubtedly face hardship. But China has substantial room for adjustment, its private consumption expenditure is only one third of its output and its current account balance of surpluses exceeded 10 percent of GDP. Increased domestic consumption can provide an important cushion to reduced exports at least in the short run and China's current account balance of payments needs to be reduced in any case as a part of rectifying global imbalances.

\section{PAKISTAN HAS NO CHOICE EXCEPT TO INCREASE EXPORT ORIENTATION}

Pakistan's exports may also suffer in the short run: textile and clothing production, a significant part of which is exported will thus face further pressure. But despite difficult international outlook, it has no real alternative to rapid export development if it wishes to create adequate employment, raise wages, improve technological capability, and meet rising obligations of debt servicing and investment income payments.

Undoubtedly Pakistan's export push will not be easy. Having missed several rounds of opportunities in international trade, it now faces stiff competition not only from China, which has expanded its market share inexorably in recent years, but also from relative new comers, India, Turkey, Mexico, Vietnam.

But there are some positives. Some of more established East Asian countries/entities, Singapore, Hong Kong, Taiwan, Malaysia, Thailand and Korea, are finding it harder to increase their market share because of rising labour costs (see Table 
4) and are shifting to more skill and technology intensive products. For instance, in textiles and clothing, exports from Korea, Hong Kong, Taiwan and even Malaysia are growing little and they are losing market share.

In the longer run, say over 10 to 15 years China may face a similar situation if its record speed of economic growth continues. China's labour surplus will not last forever though right now this prospect may be difficult to visualise. Also, as mentioned above, China's large current account balance of payments surpluses, a reflection of global imbalances, cannot continue indefinitely. The pressures of domestic consumption along with policy shifts such as exchange rate appreciation will, on the one hand, slow down export growth from China and on the other hand increase imports into China. The opportunities for poor and populous Asian countries like India, Pakistan, Bangladesh, would remain substantial.

Increased trade with neighbours especially India holds considerable promise and should be seriously pursued.

It must also be stressed that Pakistan's very low share in manufactured exports other than textiles and clothing should be viewed as a source of major opportunities. Similarly the rise in world grain prices can give new lease of life to Pakistan's agriculture. Finally, even in textiles and clothing which are the most problematic areas at present, the low level of productivity and low levels of valued added provides a great scope for improving competitiveness and raising export earnings. Foreign investment from countries or entities, Korea, Taiwan, Hong Kong who are facing limits in their own textile industries could be a source of capital, know-how and market access.

But the vision for rapid export development must give a central place to the very speedy growth of manufactured goods other than textiles and clothing for which our presence in world markets is trifling and exploiting the untapped potential of agricultural, horticultural, dairy and fisheries exports. A major transformation of the economy towards exports orientation on the scale that is being suggested here would involve a major role of the state not only in providing the overall vision but also in supporting, guiding and facilitating the progress especially in areas outside textiles and clothing.

\section{RAISING SAVING AND INVESTMENT LEVELS}

Pakistan's gross investment rate was 20 percent of GDP in 2007-08 and is likely to drop this year. National savings last year dropped to 12 percent of GDP as current account balance of payments deficit rose to a record level. Net savings reached a nadir of probably 4-5 percent of GDP. Public savings have once again become significantly negative ( 3 percent of GDP) as revenue growth has not kept pace with growing current expenditure especially security spending and interest payments. Political uncertainty has dampened both investment and savings and have encouraged capital flight. Reversal of these trends is essential; in the medium term aim should be to raise gross national savings to at least 20 percent of GDP and investment rate to at least 25 percent of GDP.

This would require an entirely different level of political commitment, a whole set of new policies to encourage savings, promoting investment and discouraging conspicuous and wasteful consumption. Fiscal policies have a central role in eliminating negative government savings by mobilising resources and ensuring a better balance between current and capital spending including present imbalance between defence and 
development outlays. At the same time, tax and expenditure need to give much more attention to equity issues, the persistent neglect of which in the past has hurt both growth and poverty alleviation efforts.

One of the biggest problems remains the low level of tax revenue...The Federal tax revenue is unlikely to show much improvement in the current year over 2007-08 in terms of the ratio to GDP (9.6 percent) because of sluggish economy and civilian unrest. Meanwhile, the interest and defense burden have risen and according to latest State Bank quarterly report are approaching 75 percent of government revenue-a situation similar to the one at the end of the 1990s.

Capital flight needs to be reversed through improvement in security position, realistic exchange rate policies and gradually building of international reserves to at least four months' foreign exchange payments.

\section{IMPORTANCE OF IMPROVING FACTOR PRODUCTIVITY}

Even with heroic efforts Pakistan would not come close to levels of saving and investment already achieved by China and India. It must therefore give special attention to improving factor productivity which is not only low but has on average grown slowly over the last forty five years: According to World Bank estimates, growth in total factor productivity (TFP) in Pakistan increased 1.2 percent per annum. ${ }^{13}$

"Two factors may explain the disappointing growth in productivity. First, after important gains made in agricultural crop productivity following the green revolution and the breakthrough in cotton in the 1980s, crop productivity growth was actually negative over 1990-2003 at least in Punjab for which data are available..... Severe drought in several years and long-term deterioration in the quality of water and soils are part of the explanation but reduced effectiveness of agricultural research and extension services also played a role" ...Second, the industrial and export sectors of Pakistan have not diversified and not increased productivity by taking advantage of the tremendous opportunities opened up by the growth in international trade, new products and new technologies."'

"But because it has fallen so far behind in world exports and apparently in levels of productivity in agriculture, industry and services, there are major possibilities for playing catch up provided strategic directions can be set right and policy actions and investments support the new priorities. Again the two areas which hold special promise for accelerated growth in TFP as well as total output are agriculture and exports". ${ }^{14}$

\section{STATE AND THE PRIVATE SECTOR}

One of the most important lessons from development experience is the need for a harmonious relationship between the public and private sector built on national interest, mutual trust and respect, and pragmatic needs of the moment. Ideological purity can be harmful.

In retrospect, the young economic leaders in Russia in the early 1990s under Gaider made mistakes in hasty privatisation and blind faith in markets. They created monopolies and oligarchs and contributed to extreme social hardship with an inevitable backlash that has resulted in the State under Putin reasserting itself. In both Russia and

\footnotetext{
${ }^{13}$ Institute of Public Policy (IPP), Beaconhouse National University, Lahore Annual Report 2008.

${ }^{14}$ IPP Ibid.
} 
Eastern Europe sufficient attention was not given to restructuring and rehabilitating salvageable state owned enterprises before deciding their future. This was in sharp contrast to Japan where after World War II the state played a major role in picking industries and firms i.e. winners in the private sector that deserved large state support and were considered worth reviving after the havoc caused by the war.

Korea deserves high marks for ensuring competition among major private sector players and at the same time maintaining open communication channels between business and government in its drive towards industrialisation especially heavy industry.

In Pakistan the relationship between the state and the private sector has long been ambivalent and marked by fair large swings in policy. On the one hand, large parts of the powerful bureaucracy have never really respected business and on the other hand large private sector firms in its relationship to government has often sought to maintain their rent-seeking positions or subsidies when losses appear. In the process resource allocation has been distorted and medium and small industries have suffered.

Much of this has changed in the last decade or so. Pakistan has a more liberal framework than a decade or so ago and institutions of restraint such as Securities and Exchange Commission and the competition Authority are becoming gradually more powerful.

Meanwhile, private sector has become much more important. The share of private investment which exceeded 50 percent of the total first time in the 1990s is now around 75 percent. Public investment has been increasingly concentrated in infrastructure areas which do not pose direction competition to the private sector, indeed facilitate private sector development. So not only has the share of private sector in investment increased but there are growing complementarities between private and public investment.

But key problems remain.

First, in the power sector, which is largely in public hands, inefficiencies and lack of investment are causing frequent breakdowns and unprecedented load shedding The costs both in terms of industrial output lost and increase in costs for the private sector by requiring alternative generating capacity have been huge. At the same time, large losses of public entities have become a significant drain on public resources. It is not clear that large scale privatisation of WAPDA's energy corporations is a quick and fully feasible answer at least in the short run.

Secondly, though much progress has been made the private sector still looks too much to the government for solving its competitiveness problems by seeking tax, credit and other concessions. Rent-seeking behaviour has not entirely disappeared and genuine entrepreneurship is still hampered though medium and small industries are faring better than before.

Third, while the large foreign investment flows are providing a more balanced source of external finance, the bulk of foreign investments are taking place in areas like energy, telecom, financial and other services which do not contribute directly to export development.

Further privatisation of public assets appears necessary because of the need for inducting additional capital, infusion of technology, and generally accelerating the pace of productivity improvements. The criteria and the process, however, need to be fully transparent and the creation of new economic rent creating situations should be avoided. 
The main point is that constructive and mutually supportive inter-face of state and private sectors remains a critical ingredient of economic success. Policies should be driven mainly by pragmatic considerations and not by emotive responses and ideological hang ups.

\section{IMPROVING PUBLIC POLICIES: FORMULATION, IMPLEMENTATION, MONITORING AND COORDINATION}

Pakistan has had in history some major economic policy failures, lack of sufficient attention to exports, shifting attitudes to private sector, totally inadequate investments in human capital, neglect of population control, and last but not least a persistent and excessive reliance on external resources for its development. But if one looks at country's past plans and policies, the rhetoric was often right in terms of goals for higher savings rates, higher level of educational attainments, reduced dependence on external assistance etc. Big problems have been the lack of effective implementation, follow up and monitoring-simply learning what is going on and what is working-and adjusting policies accordingly and consequently not learning from own and others' experience. This is where the contrast with countries like Korea is most striking.

Will implementation be more successful than in the past? Apart from development of effective forums for dialogue and consensus building with the private sector discussed above, two areas desperately require urgent attention:

- Reinvigorating planning processes to monitor progress and deal effectively with economic crises and handling economic shocks.

- Close coordination of economic policies across ministries, agencies, and provincial governments and clear delineation of responsibility for top economic leadership.

Four or Five year plans have rightly gone out of fashion but need for medium and long term planning processes remains. 1960s were hey days of planning in Pakistan and its development efforts were hailed as a rare success story. However, it was not necessarily the quality of the Second and Third Plans that made planning effective. ${ }^{15}$

"What sets the 1960s apart from the other periods in Pakistan's economic history is the central role given to the planning process as a tool of economic policy-making and coordination. The policy parameters were continuously shifting, as they often do, but it was the responsibility of the Planning Commission to try to maintain a coherent development perspective in a longer term context and attempt to resolve conflicts among policy objectives". 16

The preparation of Medium Term Economic Framework and Poverty Reduction Strategy Papers, at both the Federal level and the Provincial level provide an important potential opportunity for invigorating planning. But the conceptual basis of work remains

${ }^{15}$ Parvez Hasan (1998), p.153. In the case of the Second Plan, larger foreign aid availability under the Indus Basin Treaty and US PL 480 made possible a more than 40 percent expansion in public sector development spending over original levels. In the case of the Third Plan, the opposite happened. The reduced foreign aid availability and increased allocation to defence led to a sharp reduction in the effective size of the planned public sector development outlays.

${ }^{16}$ Parvez Hasan, p. 152. 
weak, professional capacity has been diluted, links between real economy and key economic targets are often very loose, and there is insufficient attention to sector plans and the mix between policy requirements and investment needs.

Planning processes are useless if they do not lead to effective and speedy policy responses to changing circumstances. This cannot happen if internal mechanisms for policy coordination do not exist or not working well as is in the case of Pakistan.

There are no cases of development where economic progress has proceeded smoothly. Economic crises occur regularly either because of overheating of the economy or large external shocks like the energy price increases. Successfully countries are able to quickly recognise changed economic circumstances and show flexibility but poor performing countries postpone adjustment often at a great ultimate cost. An excuse for delay is the hope that a negative external shock will not last though there is a tendency to treat a positive external shock like an improvement in the terms of trade as permanent.

The lesson of history is that a crisis should not be allowed to go to waste and should be considered as an opportunity to tackle deep seated problems. Better planning processes and close economic coordination cannot substitute for economic will but can certainly improve the chances of rational decision-making.

\section{TURNAROUND IN PAKISTAN?}

There are no signs yet that Pakistan government is tackling its multi-faced crises with a broad national determination to deal with fundamental problems of poor governance, lack of resources mobilisation for the public sector, and low taxation on the rich and the well to do to create more room for programmes for the poor.

Instead it is looking once gain to large scale external assistance to maintain unsustainable levels of consumption. There is no announced external finance policy. It would help if the government adopts a clear goal that current account balance payments deficits will not be allowed over the medium term to exceed 20 percent of investment. This will ensure that 80 percent of investment is financed from domestic resources and that unlike the past large external flows, either private or official, will not be a substitute for domestic savings. 